\title{
STUDENTS' CONCEPTUAL UNDERSTANDING IN TERMS OF GENDER DIFFERENCES
}

\author{
Nurul Azizah $^{1_{\iota}}{ }^{*}$, Budiyono $^{2}$, and Siswanto ${ }^{3}$ \\ 1Postgraduate Program of Mathematics Education, Universitas Sebelas Maret, Jalan Ir. Sutami No. \\ 36A, Surakarta 57126, Indonesia \\ ${ }^{2}$ Faculty of Teacher Training and Education, Universitas Sebelas Maret, Jalan Ir. Sutami No. 36A, \\ Surakarta 57126, Indonesia \\ ${ }^{3}$ Faculty of Mathematics and Natural Sciences, Universitas Sebelas Maret, Jalan Ir. Sutami No. 36A, \\ Surakarta 57126, Indonesia \\ * Email: nurulazizah23@student.uns.ac.id
}

\begin{abstract}
Abstrak: Salah satu kemampuan dasar yang harus dimiliki siswa dalam belajar matematika adalah kemampuan pemahaman konsep. Kemampuan ini dapat dipengaruhi dari perbedaan gender masing masing siswa. Tujuan dari penelitian ini adalah menganalisis pemahaman konsep siswa dalam menyelesaikan soal himpunan ditinjau dari perbedaan gender. Penelitian ini menggunakan metode deskriptif kualitatif. Subjek penelitian adalah siswa kelas IX SMP N 3 Surakarta. Instrumen penelitian ini menggunakan tes kemampuan pemahaman konsep. Hasil penelitian menunjukan bahwa pada Siswa dengan gender laki-laki memiliki pemahaman konsep yang baik dalam menerapkan konsep dalam pertihungan matematis dan menerjemahkan gambar dalam soal menjadi bentuk lain, 2) Siswa dengan gender perempuan memiliki pemahaman konsep yang cukup baik dalam menerjemahkan gambar dalam soal menjadi bentuk lain, walaupun masih lemah dalam menentukan konsep-konsep yang tepat untuk digunakan dalam menyelesaikan soal dan menerapkan konsep dalam pertihungan matematis.
\end{abstract}

Kata kunci : Gender, Theorema Pythagoras, dan Pemahaman Konsep

\begin{abstract}
One of the basic skills that students must master to learn mathematics is conceptual understanding. Gender differences have an influence on the disparity level of students' conceptual understanding. This research is qualitative descriptive research that aimed to analyze the students' conceptual understanding in solving set problems in terms of gender differences. The research subjects were 9th-grade students of SMP N 3 Surakarta. The concept understanding ability test was used as a research instrument. The results showed that male students had an excellent conceptual understanding in applying concepts in mathematical calculations and translating images into other forms of interpretation, 2) Female students had a fairly good conceptual understanding in translating images into other forms of interpretation, although female students tend to be weak in determining the right concepts to be used in solving problems and applying concepts in mathematical calculations.
\end{abstract}

Keywords: Conceptual Understanding, Gender, and Pythagorean Theorem

\section{INTRODUCTION}

Mathematics is one of the field studies that plays an important role in education and community life. According to NCTM, the purpose of learning mathematics is to represent concepts (Kadir et al., 2018; Weintrop et al., 2016). The process of obtaining a complete understanding is very important to be noticed in education. Mathematics education should be able to broaden students' horizons to be able to apply mathematical concepts in everyday life. Understanding the concepts have a higher meaning than simply keep in mind or memorizing concepts. The students who have mastered the conceptual understanding means that he has gone through the memorizing and has succeeded in interpreting the meaning of a concept which is characterized by the ability to construct messages through spoken, 
written, or graphic messages (Bell, 2008; Nasution \& Hafizah, 2020; Sagala et al., 2019) being able to explain the concepts they get and be able to provide examples related to the concepts (Panaoura et al., 2017) provide an understanding that the materials taught to the students are not just memorization. Indicators that show that the students have mastered understanding mathematical concepts are: 1) the students are able to translate an abstract concept into a model (translation), 2) the students are able to recognize and understand the main idea of information (interpretation), 3) the students are able to conclude information and look for a solution to a specific problem (extrapolation) (Wahyuningsih, 2014). The problem that often occurs today is that the students often experience difficulties in understanding a concept, especially in understanding mathematical concepts which are often abstract. This is because the students' ability to form a concept within themselves is still lacking, the student's readiness in receiving the lessons is still not optimal, students' learning habits and styles, students who are less motivated during the learning process and less attractive learning models, and inappropriate teacher learning strategies (Sayekti et al., 2019).

The students' low understanding of concepts in mathematics can be found in almost all schools in Indonesia. As found in Lampung, Surakarta, Sukoraja, Central Java, in the UN scores for SMA in Indonesia (Puspendik, 2019) and many other schools also find the same problems. The result of PISA in 2018 also support the statements of these studies. Based on the result of PISA 2018, Indonesian's mathematical literacy skills which generally measure in the C2-C6 domain, where conceptual understanding is also measured in it, states in that year there is decreased when compared to PISA result in 2015. Based on the results of interviews with teachers, the low students' conceptual understanding is influenced by the lack of students' ability to form a concept in their minds and students' lack of readiness to accept lessons. Moreover, there are several other internal factors, such as low self-efficacy of students which makes students easily give up when they find difficulties in understanding concepts that lead to difficulties in solving problems. Low prior knowledge of students is also a factor that affects the learning process. Prior knowledge is defined as the starting point in the learning process. This is in accordance with the results of the study by Purwaningrum \& Sumardi (2016) which stated that students' mathematics' prior knowledge is the most influential factor on mathematics learning outcomes.

Another factor that can affect the ability to understand concepts is gender (Winata \& Friantini, 2020). Gender is a term to describe the differences between men and women who have innate characteristics (God's creation) and cultural formation (social construction), including their differences in solving problems. Men and women do look different and have different sex organs and hormones, and therefore it is thought that men and women must also differ in the way they think, act and feel. Boys do slightly better than girls in math and science. Boys do slightly better than girls in math and science. In general, male students are the same as female students, however male students have better abstraction power than female students, so that it allows the male students to be better than female students in the mathematics, because generally mathematics is concerned with abstract understanding (JW, 2007). 
Based on previous research, there have been many researchers who have examined students' understanding of concepts (Fachrurrozy \& Saehana, 2017; Jafari Koshkouei et al., 2016; Lestari et al., 2019; Nasution \& Hafizah, 2020; Şengül \& Katranci, 2014) as well as studies that have examined gender differences (Lindberg et al., 2010; Niederle \& Vesterlund, 2010; Sagala et al., 2019; Tao \& Michalopoulos, 2020). However, there is still no research that analyzes the mathematical conceptual understanding of students of SMP Negeri 3 Surakarta in terms of gender differences, especially in the material pythagoras theorem. Therefore, the aim of this study is to analyze students' understanding of concepts in solving set problems in terms of gender differences.

\section{RESEARCH METHOD}

This study used descriptive qualitative method. The subjects in this study were 6 students who were taken from class IX students of SMP N 3 Surakarta in the odd semester of the 2020/2021. The technique of taking the subject uses purposive sampling. The purpose of selecting subjects by purposive sampling, namely research subjects in accordance with the phenomenon in the focus of the study (Creswell, 2012). The instrument in this study was a test of concept comprehension ability which is a form of description test in order to see students' conceptual understanding. Furthermore, the triangulation method is used to validate the data. The triangulation method emphasizes the use of different data collection methods or methods for the same data. (Budiyono, 2017). The data analysis technique in this study was focused during the process in the field along with data collection. (Sugiyono, 2013). After the data is collected, the researcher can reduce the data or present the data. Data reduction and data presentation activities can be reciprocal, which means that they can reduce the data first or present data beforehand. Data reduction and drawing conclusions are reciprocal. Henceforth, after the conclusion is obtained and felt that it has not been able to produce a convincing theory, then the researcher can collect the data again .

\section{RESULTS AND DISCUSSION}

In this session, the results of research and data analysis will be presented. The results of the study were the results of the conceptual understanding ability test and interviews. The test consists of 3 questions and 1 question contains 1 indicator of conceptual understanding, where the indicators are, 1) students are able to apply concepts in mathematical calculations to solve problems or conclude information that has been known (extrapolation), 2) students are able to determine concepts the right concept to be used to solve the problem (interpretation), 3) students are able to translate the sentence in the problem into another sentence (translation). Tables 1 and 2 describe the summary results of the analysis of students' conceptual understanding abilities based on each gender group. 
Table 1 Analysis of Conceptual Understanding of Male Students

\begin{tabular}{|c|c|c|c|}
\hline \multirow{2}{*}{ Subject } & \multicolumn{3}{|c|}{ Indicator } \\
\hline & extrapolation & interpretation & translation \\
\hline SL-01 & $\begin{array}{l}\text { In the first problem, SL-01 } \\
\text { was able to conclude the } \\
\text { information well, } \\
\text { illustrating the right } \\
\text { drawing sketch to the } \\
\text { solution form using the } \\
\text { Pythagorean theorem. }\end{array}$ & $\begin{array}{l}\text { In the second question, SL- } \\
01 \text { did not seem to } \\
\text { understand the main idea of } \\
\text { the questions given and was } \\
\text { confused in concluding the } \\
\text { results, so the answer is not } \\
\text { correct. }\end{array}$ & $\begin{array}{l}\text { In the third problem, SL- } 01 \text { was } \\
\text { able to translate concepts from } \\
\text { block images and capture } \\
\text { information well so that SL- } 01 \\
\text { could apply the Pythagorean } \\
\text { theorem to the problem } \\
\text { correctly. }\end{array}$ \\
\hline SL-02 & $\begin{array}{l}\text { In the first question, SL- } \\
02 \text { was able to conclude } \\
\text { the information well and } \\
\text { write in detail what was } \\
\text { known from the questions } \\
\text { so that SL- } 02 \text { was able to } \\
\text { answer the questions } \\
\text { properly and completely. }\end{array}$ & $\begin{array}{l}\text { In the second question, SL- } \\
02 \text { was able to understand } \\
\text { the main idea of the } \\
\text { question correctly and } \\
\text { answered the question well, } \\
\text { yet SL-02 did not explain in } \\
\text { detail how to get the } \\
\text { difference in the height of } \\
\text { the two poles. }\end{array}$ & $\begin{array}{l}\text { In the third question, SL-02 } \\
\text { was able to translate the image } \\
\text { of a block on the question into } \\
\text { a structured solution form using } \\
\text { the Pythagorean theorem } \\
\text { correctly. }\end{array}$ \\
\hline SL-03 & $\begin{array}{l}\text { In the first problem, SL- } 03 \\
\text { understood and captured } \\
\text { the information given in } \\
\text { the problem precisely, so } \\
\text { SL-03 could determine the } \\
\text { distance using the } \\
\text { Pythagorean theorem. }\end{array}$ & $\begin{array}{l}\text { In the second question, SL- } \\
03 \text { did not fully understand } \\
\text { the problem. SL-03 was } \\
\text { confused to determine what } \\
\text { was known and could not } \\
\text { apply the Pythagorean } \\
\text { theorem to solve the } \\
\text { problem. }\end{array}$ & $\begin{array}{l}\text { In the third problem, SL-03 was } \\
\text { able to translate the block } \\
\text { image into a form of solution } \\
\text { using the Pythagorean theorem. } \\
\text { The answer given by SL-03 } \\
\text { was complete and correct. }\end{array}$ \\
\hline
\end{tabular}

From 18 male students, three students were selected to be analyzed more deeply by interview. Based on the data in Table 1, it can be seen that the three students were able to work on the questions from extrapolation and translation indicators, but two students failed in the interpretation indicator. The three male students were able to apply concepts in mathematical calculations to solve problems and conclude information by using the Pythagorean theorem correctly, students were able to translate the image of a given block in the form of sentences and answers correctly, and one of the students was able to determine a suitable concept to be used in solving the Pythagorean problem.

Table 2 Analysis of Conceptual Understanding of Female Students

\begin{tabular}{llll}
\hline \multirow{2}{*}{ Subject } & \multicolumn{1}{c}{ Indicator } \\
\cline { 2 - 5 } & \multicolumn{1}{c}{ extrapolation } & \multicolumn{1}{c}{ interpretation } \\
\hline SP-01 & In the first question, SP- & In the second question, SP-01 In the third question, SP-01 \\
& 01 was able to understand & could not conclude the was able to translate \\
the question and was able & information that known from concepts from block \\
to sketch a picture of the & the problem, could not images, SP-01 answered \\
question so that SP-01 & understand the problem well, and the question using the \\
could answer the & could not answer the question Pythagorean theorem \\
questions well. & $\begin{array}{l}\text { correctly using the Pythagorean correctly. } \\
\text { theorem. }\end{array}$
\end{tabular}




\begin{tabular}{|c|c|c|}
\hline \multirow{2}{*}{ Subject } & \multicolumn{2}{|l|}{ Indicator } \\
\hline & interpretation & translation \\
\hline SP-02 & $\begin{array}{l}\text { In the first problem, SP- In the second question, SP-02 } \\
02 \text { did not understand the was able to understand the } \\
\text { information given in the question well and SP-02 could } \\
\text { problem, so SP-02 could also determine the right concept } \\
\text { not determine the to be used to solve the problem. } \\
\text { distance using the } \\
\text { Pythagorean theorem. }\end{array}$ & $\begin{array}{l}\text { In the third question, SP-02 } \\
\text { was able to translate the } \\
\text { image using the } \\
\text { Pythagorean theorem into a } \\
\text { solution form. SP-02 } \\
\text { answered the question } \\
\text { correctly. }\end{array}$ \\
\hline SP-03 & $\begin{array}{l}\text { In the first problem, SP- } \text { In the second question, SP-03 } \\
03 \text { was unable to was able to deduce information } \\
\text { conclude the information from the question and understand } \\
\text { presented in the problem, the question well so that SP-03 } \\
\text { SP-03 also failed to apply could solve the problem } \\
\text { the Pythagorean theorem correctly. } \\
\text { correctly to solve the } \\
\text { problem. }\end{array}$ & $\begin{array}{l}\text { In the third question, SP-03 } \\
\text { was able to translate the } \\
\text { block image in the form of } \\
\text { solutions and answered the } \\
\text { questions correctly. }\end{array}$ \\
\hline
\end{tabular}

The total subject of female students is 12 , and 3 subjects that meet the criteria are selected to be analyzed more deeply through interviews. Based on table 2, it can be seen that the three students met the translation indicator. However, two students had not been able to meet the interpretation and extrapolation indicators. The three students were able to translate the pictures in the question into a good form of completion using the Pythagorean theorem, although there were still a few inaccuracies. And on the extrapolation indicator, two students can sketch a picture of the information in the question. In the interpretation indicator, two students were able to conclude information from the question, but they did not understand the question well, so they could not solve the problem correctly.

Based on the research findings that have been described, it is known that male students tend to have better conceptual understanding skills than female students. Male students can conclude information and find a way to solve a problem well. They can also translate pictures into a mathematical solution model appropriately. Female students tend to have a good understanding of concepts in translating sentences or pictures in other interpretations. However, of the three students who were analyzed in more depth, two of them did not master the indicators of interpretation and extrapolation, so they could not determine the right concepts to solve the problem.

Based on the previous explanation, it can be concluded that male students tend to have better conceptual understanding skills than female students. This indicates that a male student understands information faster than a female student during the learning process. Male students will find it easier to understand a concept. The construction of concepts learned by an individual is influenced by gender, so that prior knowledge-oriented learning is believed to have an impact on the learning process so that the acquisition of learning outcomes better. This is in line with the research conducted by Asmaningtias (2012), which stated that male students in the learning process have better mathematical abilities and have no difficulty understanding mathematical concepts. Based on the results of the previous discussion, 
it can be concluded that students' prior knowledge affects conceptual understanding, and students' understanding of mathematical concepts can be improved in various ways, one of which is by applying a learning model that is considered effective in supporting the learning process and learning achievements.

\section{CONCLUSSIONS AND SUGGESTIONS}

Based on the results of the research analysis, it can be concluded that: 1) Male students have good abilities in applying concepts in mathematical calculations and translating images in questions into other forms, 2) Female students had a fairly good conceptual understanding in translating images into other forms of interpretation, although female students tend to be weak in determining the right concepts to be used in solving problems and applying concepts in mathematical calculations.

Based on the research that has been done, it is hoped that students can improve arithmetic operations both with routine and non-routine exercises and get used to checking answers before they are collected. Mathematics learning that is developed should not be emphasized on memorizing formulas but aims to increase students' mastery of concepts. For further research, this research can be a reference, source of information, and reference material, so that it can be developed further on other subjects to improve the quality of learning.

\section{REFERENCES}

Asmaningtias, Y. T. (2012). Kemampuan Matematika Laki-Laki Dan Perempuan. Madrasah.

Bell, F. (2008). Teaching and Learning Mathematics (in Secondary School). Wm. C. Brown Company Publishers.

Budiyono. (2017). Pengantar Metodologi Penelitian Pendidikan. UNS Press.

Creswell, W. J. (2012). Educational Research: Planning, Conducting, and Evaluating Quantitative and Qualitative Research (4 thed). Pearson Prentice-Hal.

Fachrurrozy, M., \& Saehana, S. (2017). Error analysis of mathematical concepts in students of Physical education courses. E-Jurnal Mitra Sains, 5(2), 1-10.

Jafari Koshkouei, H., Shahvarani, A., Behzadi, M. H., \& Rostamy-Malkhalifeh, M. (2016). Structural Modeling for Influence of Mathematics Self-Concept, Motivation to Learn Mathematics and SelfRegulation Learning on Mathematics Academic Achievement. Mathematics Education Trends and Research, 2016(1), 1-12.

JW, S. (2007). Perkembangan Anak Jilid 2. Erlangga.

Kadir, K., Fatma, M., \& Rizki Heryani Oktavianti, R. (2018). Development of KADIR Learning Model to Enhance Studentsr Mathematical Problem Solving Skill. Advances in Social Science, Education and Humanities Research, 115(Icems 2017), 110-116.

Lestari, F., Saryantono, B., Syazali, M., Saregar, A., Jauhariyah, D., \& Umam, R. (2019). Cooperative Learning Application with the Method of Network Tree Concept Map : Based on Japanese Learning System Approach. Journal for the Education of Gifted Young Scientists, 7(1), 15-32.

Lindberg, S. M., Hyde, J. S., Petersen, J. L., \& Linn, M. C. (2010). New Trends in Gender and 
Mathematics Performance: A Meta- Analysis. NIH Public Access, 136(6), 1123-1135.

Nasution, M. L., \& Hafizah, N. (2020). Development of students' understanding of mathematical concept with STAD type cooperative learning through student worksheets. Journal of Physics: Conference Series, 1554, 012035.

Niederle, M., \& Vesterlund, L. (2010). Explaining the Gender Gap in Math Test Scores : The Role of Competition. Journal OF Economic Perspectives, 24(2), 129-144.

Panaoura, A., Michael-Chrysanthou, P., Gagatsis, A., Elia, I., \& Philippou, A. (2017). A Structural Model Related to the Understanding of the Concept of Function: Definition and Problem Solving. International Journal of Science and Mathematics Education, 15(4), 723-740.

Purwaningrum, D., \& Sumardi, S. (2016). Efek Strategi Pembelajaran Ditinjau dari Kemampuan Awal Matematika terhadap Hasil Belajar Matematika Kelas XI IPS. Manajemen Pendidikan.

Puspendik. (2019). Hasil Ujian Nasional.

Sagala, R., Umam, R., Thahir, A., Saregar, A., \& Wardani, I. (2019). The Effectiveness of STEM-Based on Gender Differences: The Impact of Physics Concept Understanding. European Journal of Educational Research, 8(3), 753-761.

Sayekti, Y., Studi, P., Matematika, P., \& Purwokerto, U. M. (2019). Pengaruh Problem Based Learning dengan Strategi "MURDER " terhadap Kemampuan Pemahaman Konsep Matematis Siswa. Journal of Mathematics Education, 5(1), 24-32.

Şengül, S., \& Katranci, Y. (2014). Effects of jigsaw technique on seventh grade primary school students' attitude towards mathematics. Procedia - Social and Behavioral Sciences, 116(2014), 339-344.

Sugiyono. (2013). Metode Penelitian Kuantitatif, kualitatif dan R \& D. In Bandung: Alfabeta.

Tao, H.-L., \& Michalopoulos, C. (2020). Gender Equality And The Gender Gap In Mathematics. J. Biosoc. Sci., 50(3), 227-243.

Wahyuningsih, D. (2014). Motivasi Belajar dan Pemahaman Konsep Fisika Siswa SMK dalam Pembelajaran Menggunakan Model Experiental Learning. Jurnal Pembelajaran Fisika, 3(1).

Weintrop, D., Beheshti, E., Horn, M., Orton, K., Jona, K., Trouille, L., \& Wilensky, U. (2016). Defining Computational Thinking for Mathematics and Science Classrooms. Journal of Science Education and Technology, 25(1), 127-147.

Winata, R., \& Friantini, R. N. (2020). Kemampuan Pemahaman Konsep Matematika Siswa Ditinjau Dari Minat Belajar Dan Gender. Journal of Mathematics Education, 6(1), 1-18. 